\title{
Mass spectrometry of polystyrene and polypropene ruthenium complexes. A new tool for polymer characterization
}

\author{
Eva Royo*, Hans-Herbert Brintzinger \\ Fakultät für Chemie, Universität Konstanz, D-78457 Konstanz, Germany
}

\begin{abstract}
The use of organometallic fragments as cationization reagents for matrix-assisted laser-desorption-ionization time-of-flight mass spectrometry (MALDI-TOF-MS) of polystyrene (PS) and polypropene (PP) is reported. Reaction of $\left[\mathrm{Ru}\left(\mathrm{C}_{5} \mathrm{H}_{5}\right)\left(\mathrm{NCCH}_{3}\right)_{3}\right][\mathrm{PF} 6]$ (1a) with PS samples of numerical mass average $M_{\mathrm{n}} 1430-135000$ in a ratio $[\mathrm{Ru}] /[\mathrm{PS}]=1 / 1$ to $3 / 1$ favours effective ionization of the polymer by MALDI-MS techniques and leads to an increase in signal intensity over that obtained by use of $\mathrm{Ag}^{+}$salts. $\mathrm{PP}$ samples of $M_{\mathrm{n}} 2700$ and 6100 are ionized after reaction with the trinuclear ruthenium pentahydride derivative $\left(\mathrm{RuC}_{5} \mathrm{Me}_{5}\right)_{3} \mathrm{H}_{5}$, thus affording the first observation of MALDI-MS signals for this polymer. Reactions of the cations $\left[\mathrm{Ru}\left(\mathrm{C}_{5} \mathrm{H}_{5}\right)\left(\mathrm{NCCH}_{3}\right)_{3}\right]^{+}$and $\left[\mathrm{Ru}\left(\mathrm{C}_{5} \mathrm{Me}_{5}\right)\left(\mathrm{NCCH}_{3}\right)_{3}\right]^{+}$with 1,3-diphenylpropane and of $\left(\mathrm{RuC}_{5} \mathrm{Me}_{5}\right)_{3} \mathrm{H}_{5}$ with 1-eicosene were studied as models for the corresponding reactions with PS and PP, respectively.
\end{abstract}

Keywords: MALDI-TOF-MS; Ru organometallics; Polymer modification; Polymer mass distribution

\section{Introduction}

For rapid screening and characterization of complicated mixtures of polymers, as they are generated e.g. by catalyst libraries produced by combinatorial methods, efficient polymer analysis methods are required [1,2]. Precise, direct and fast methods for the characterization of mixtures of polyolefins still have to be developed, since conventional GPC and NMR methods cannot be accelerated beyond certain limits. Furthermore, some essential structural elements of the polymer chain, such as block lengths in block copolymers or lengths of chain branches, are hardly amenable to routine analysis by conventional techniques.

In this regard, mass spectrometry presents unique features for an exact, direct, fast and inexpensive characterization of polymer materials [3,4]. For many

* Corresponding author. Present address: Departamento de Química Inorgánica, Instituto de Ciencia de Materiales de Aragón, Universidad de Zaragoza-CSIC, Pza. San Fransisco s/n, E-50009 Zaragoza, Spain. Tel.: +34-976-761000/ext.3296; fax: +34-976-761187

E-mail address: evaroyo@posta.unizar.es (E. Royo). years, mass spectrometry of intact synthetic polymers has been limited to field desorption mass spectrometry (FD-MS). Modern soft ionization techniques [5] such as electrospray ionization (EI) and matrix assisted laser desorption ionization (MALDI), which have had enormous impact on the analysis of biopolymers [6], are nowadays increasingly recognized as valuable tools for the characterization also of synthetic polymers [4,79]. MALDI-TOF-MS is, in principle, ideally suited for this purpose because of the simplicity of the mass spectra (mainly singly charged molecular ions with hardly any fragmentation) and the high mass ranges accessible with a time-of-flight analyzer, for which extension up to 1 million Da has been reported [7].

Application of MS to polymers with high molar masses has been limited mainly by difficulties to ionize these molecules [10]. Ionization of synthetic polymers in MALDI-MS is usually induced by complexation with a cation. Synthetic polymers containing heteroatoms often show cationization after addition of $\mathrm{Na}^{+}$or $\mathrm{K}^{+}$ salts [8]. Apolar synthetic polymers containing double bonds, such as polystyrene or polydienes, can be ionized after addition of $\mathrm{Ag}^{+}$or $\mathrm{Cu}^{2+}$ salts $[4,7,9]$. Polymers without heteroatoms and double bonds are, with 
singular exceptions [11], not amenable to MALDI analysis and chemical ionization (CI) or FD are alternatives only to a limited extent [12].

The ionization reagent must effectively ionize the polymer without disturbing a favorable cocrystallization behavior of the matrix and the polymer [9]. This problem is aggravated when $\mathrm{Ag}^{+}$or $\mathrm{Cu}^{2+}$ salts are used to induce ionization of nonpolar polymers in a matrix such as all-trans-retinoic acid or dithranol, which are generally used for this purpose, in that these ions appear to interact also with the matrix: all-trans-retinoic acid is slowly oxidized in the presence of $\mathrm{Ag}^{+}$or $\mathrm{Cu}^{2+}$, while the stability of mixtures of $\mathrm{Ag}^{+}-\mathrm{PS}$-dithranol is limited to a few minutes. Cation adduct formation both with the polymer and the matrix obviously requires additional research [4].

Our approach to solve these problems has been to modify the polymer by a well-defined reaction with an organometallic reagent, so as to form a polymer-bound organometallic species, which acts as an easily ionizable center for the formation of polymer ions.

\section{Results and discussion}

\subsection{Organometallic modification of polystyrene}

For the introduction of a metal center into polystyrene chains, we have investigated in this first study the use of $\mathrm{Ru}\left(\mathrm{C}_{5} \mathrm{R}_{5}\right)$ complexes, since cationic arene$\mathrm{Ru}\left(\mathrm{C}_{5} \mathrm{R}_{5}\right)$ derivatives are rather easily accessible from complexes of the general type $\left[\mathrm{Ru}\left(\mathrm{C}_{5} \mathrm{R}_{5}\right)\left(\mathrm{NCCH}_{3}\right)_{3}\right][\mathrm{A}]$ with $\mathrm{R}=\mathrm{H}$ and $\mathrm{A}=\mathrm{PF}_{6}(\mathbf{1 a})$ or $\mathrm{CF}_{3} \mathrm{SO}_{3}(\mathbf{1 b})$ and with $\mathrm{R}=\mathrm{Me}$ and $\mathrm{A}=\mathrm{BF}_{4}(\mathbf{1 c})$ by direct thermal substitution of the acetonitrile ligands (Scheme 1) [13,14]. These complexes are fairly air stable and are advantageous also in that simple mass spectra without complicated signal distributions due to loss of one or more ligands from the metal center are to be expected from the presence of a single cyclopentadienyl ligand in the final polystyrene complex.

When polystyrene samples with different known molar masses $\left(1340<M_{\mathrm{n}}<135000\right)$ were reacted with an equivalent amount or a slight excess of complex 1a per mol of polymer in 1,2-dichloroethane solution at $50-60{ }^{\circ} \mathrm{C}$ for $10-15 \mathrm{~min},{ }^{1} \mathrm{H}-\mathrm{NMR}$ spectra of the reaction mixture showed that complex 1a was completely consumed. Evaporating the solvent under reduced

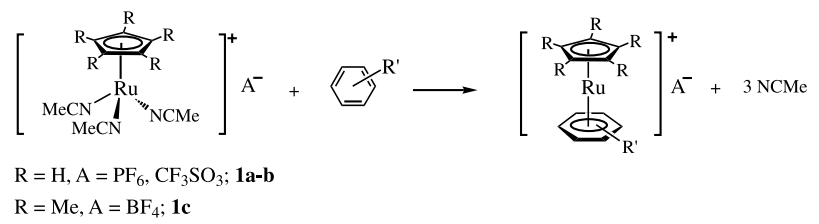

Scheme 1. Route to cationic arene- $\mathrm{Ru}\left(\mathrm{C}_{5} \mathrm{R}_{5}\right)$ derivatives.
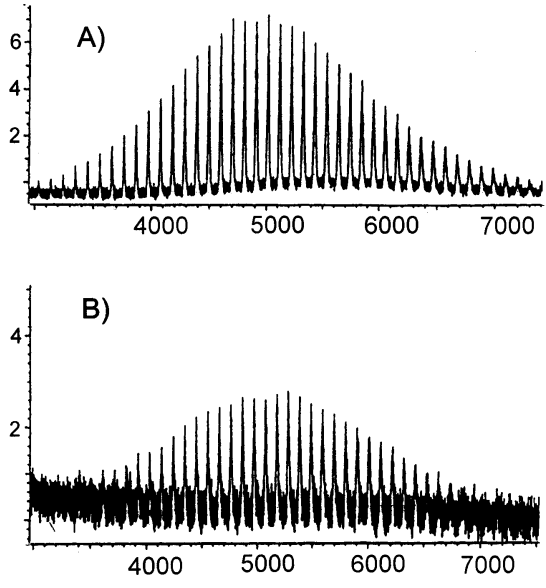

Fig. 1. MALDI mass spectra of polystyrene with $M_{\mathrm{n}}=5050$ (alltrans-retinoic acid matrix) after reaction with an equimolar amount of $\left[\mathrm{Ru}\left(\mathrm{C}_{5} \mathrm{H}_{5}\right)\left(\mathrm{NCCH}_{3}\right)_{3}\right]^{+}$(top, A) and after reaction with an equimolar amount of $\mathrm{Ag}^{+}$in EtOH (bottom, B).

pressure and subsequent re-dissolving the remaining white powder in THF yielded a clear solution, which was analyzed by MALDI-TOF-MS using all-transretinoic acid as matrix (Section 3). In each of these experiments, a unique polystyrene signal distribution was obtained (Figs. 1-3). The signal-to-noise ratio (S/N) of these spectra is three to four times greater than that produced with stoichiometric amounts of $\mathrm{Ag}^{+} \mathrm{NO}_{3}^{-}$as cationization reagent (Fig. 1).

For polymers with high molar masses the possibility of creating multiply charged distributions of formula $[\mathrm{P}-\mathrm{nM}]^{n+}$ (where $\mathrm{P}$ is the polymer and $\mathrm{M}$ is a metal center) is a known feature that has been successfully applied to MALDI analysis of polystyrene with high molar masses by silver ionization [7]. Since polycationic
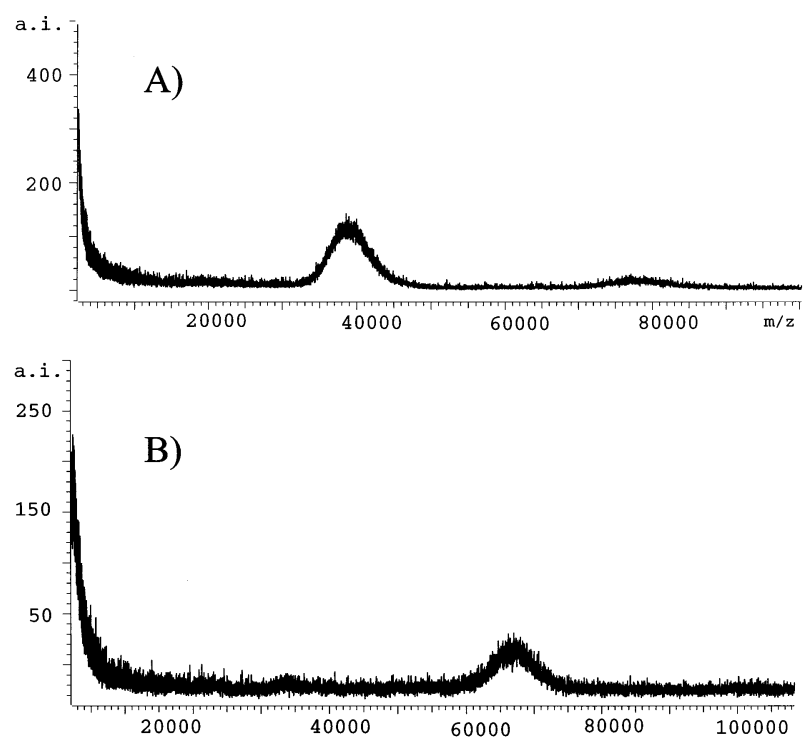

Fig. 2. MALDI mass spectra of two polystyrene samples with $M_{\mathrm{n}}=$ 39000 (top, A) and $M_{\mathrm{n}}=66000$ (bottom, B) after reaction with equimolar amounts of $\left[\mathrm{Ru}\left(\mathrm{C}_{5} \mathrm{H}_{5}\right)\left(\mathrm{NCCH}_{3}\right)_{3}\right]^{+}$. 

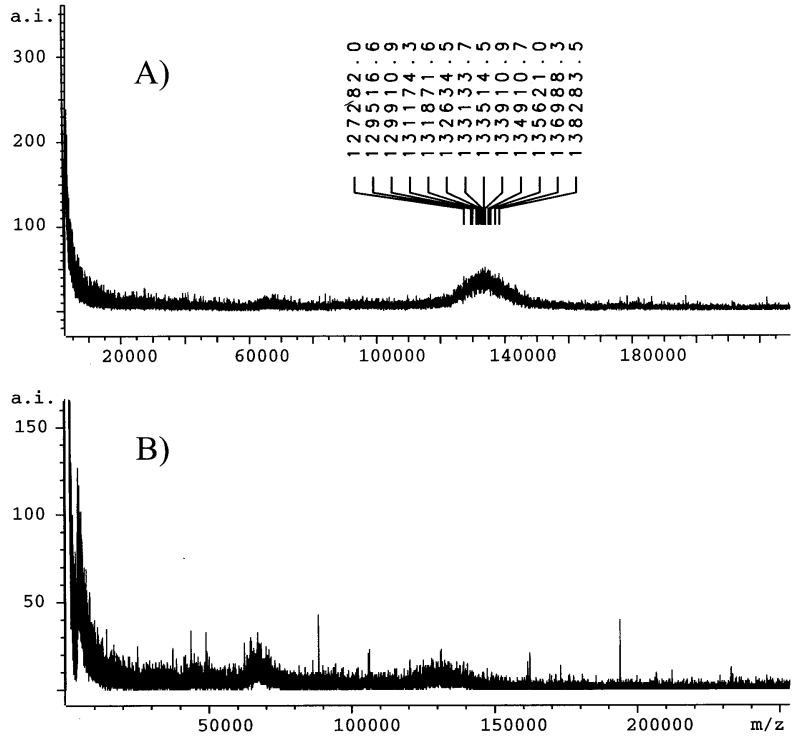

Fig. 3. MALDI mass spectra of polystyrene with $M_{\mathrm{n}}=135000$ (alltrans-retinoic acid matrix) after reaction with $\left[\mathrm{Ru}\left(\mathrm{C}_{5} \mathrm{H}_{5}\right)\left(\mathrm{NCCH}_{3}\right)_{3}\right]^{+}$ in ratios $[\mathrm{Ru}] /[\mathrm{PS}]=1 / 1$ (Top, $\mathrm{A}$ ) and $[\mathrm{Ru}] /[\mathrm{PS}]=10 / 1$ (bottom, $\mathrm{B}$ ).

complexes containing more than one $\left[\mathrm{Ru}\left(\mathrm{C}_{5} \mathrm{H}_{5}\right)\right]^{+}$unit attached to hydrocarbons with several aromatic units are also well documented [15], we have investigated which effects the addition of more than one equivalent of the ruthenium reagent has on the MALDI polystyrene signal.

The use of a higher [Ru]/[PS] ratio (from $5 / 1$ to 20/1) has severe effects on the final spectra for polystyrene up to $M_{\mathrm{n}} \approx 135000$ (Fig. 3). The signal intensity of the singly charged ions is substantially decreased due to a statistical fragmentation of the polymer. The type of matrix used also affects the degree of fragmentation $[4,16,17]$; fragments were less abundant when all-transretinoic acid instead of dithranol was used as matrix. Polymers with $M_{\mathrm{n}}$ over 135000 did not give rise to any detectable signals.

In order to get a more detailed picture of the structure and the fragmentation processes of this polymer-cation adduct, we have investigated model complexes of general formula $\left[\mathrm{Ru}\left(\mathrm{C}_{5} \mathrm{R}_{5}\right)\left(\eta^{6}-\mathrm{C}_{6} \mathrm{H}_{5}\right)\left(\mathrm{CH}_{2}\right)_{3}\left(\eta^{6}-\mathrm{C}_{6} \mathrm{H}_{5}\right)\right.$ $\left.\mathrm{Ru}\left(\mathrm{C}_{5} \mathrm{R}_{5}\right)\right][\mathrm{A}]_{2}$ (Scheme 2).

For this purpose, one equivalent of 1,3-diphenylpropane was reacted with two equivalents of the appropriate complex $\left[\mathrm{Ru}\left(\mathrm{C}_{5} \mathrm{R}_{5}\right)\left(\mathrm{NCCH}_{3}\right)_{3}\right][\mathrm{A}](\mathbf{1 a})-(\mathbf{1 c})$ in 1,2-dichloroethane solution at room temperature for 2 h. In all three cases, evaporation of the solvent produced a white powder which was re-dissolved in $\mathrm{CD}_{3} \mathrm{CN}$ and identified by ${ }^{1} \mathrm{H}-\mathrm{NMR}$ as the dinuclear complexes $\left[\mathrm{Ru}\left(\mathrm{C}_{5} \mathrm{R}_{5}\right)\left(\eta^{6}-\mathrm{C}_{6} \mathrm{H}_{5}\right)\left(\mathrm{CH}_{2}\right)_{3}\left(\eta^{6}-\mathrm{C}_{6} \mathrm{H}_{5}\right) \mathrm{Ru}\left(\mathrm{C}_{5} \mathrm{R}_{5}\right)\right][\mathrm{A}]_{2}$ with $\mathrm{R}=\mathrm{H}$ and $\mathrm{A}=\mathrm{PF}_{6}$ (2a) or $\mathrm{CF}_{3} \mathrm{SO}_{3}$ (2b) and with $\mathrm{R}=\mathrm{Me}$ and $\mathrm{A}=\mathrm{BF}_{4}(\mathbf{2 c})$.

Attempts to prepare the mononuclear complexes by reacting equimolar amounts of the reactants gave product mixtures with ${ }^{1} \mathrm{H}-\mathrm{NMR}$ spectra which indicated the formation of both, the mononuclear compound $\left[\mathrm{Ru}\left(\mathrm{C}_{5} \mathrm{R}_{5}\right)\left(\eta^{6}-\mathrm{C}_{6} \mathrm{H}_{5}\right)\left(\mathrm{CH}_{2}\right)_{3}\left(\mathrm{C}_{6} \mathrm{H}_{5}\right)\right]\left[\mathrm{PF}_{6}\right]$ and the dinuclear derivative 2a in a 1:1 ratio, from which we could not isolate the pure mononuclear complex. These observations allow us to conclude that polystyrene complexes with more than one $\left[\mathrm{Ru}\left(\mathrm{C}_{5} \mathrm{R}_{5}\right)\right]^{+}$unit per polystyrene chain are also formed even when a stoichiometric 1:1 ratio was used.

Since it is known that certain matrices favor detection of multiply charged species, we used one of these, $\alpha$ cyano-4-hydroxycinnamic acid, to analyze compounds 2a-c by MALDI-MS following the dried-droplet procedure $[4,5]$. The observed ions in the positive mode are listed in Table 1. Surprisingly, the highest $\mathrm{m} / \mathrm{z}$ value for all three species (673 for $\mathbf{2 a}, 677$ for $\mathbf{2 b}$ and 755 for $\mathbf{2 c}$ ) corresponds to a singly charged ion pair $\left[\mathrm{Ru}\left(\mathrm{C}_{5} \mathrm{R}_{5}\right)\left(\eta^{6}\right.\right.$ $\left.\left.\mathrm{C}_{6} \mathrm{H}_{5}\right)\left(\mathrm{CH}_{2}\right)_{3}\left(\eta^{6}-\mathrm{C}_{6} \mathrm{H}_{5}\right) \mathrm{Ru}\left(\mathrm{C}_{5} \mathrm{R}_{5}\right)^{2+}+\mathrm{A}^{-}\right]^{+}$, with isotope patterns in agreement with expectations (Fig. 4). Doubly charged ions were not observed, even when the $\mathrm{PF}_{6}^{-}$counterion was substituted by $\mathrm{CF}_{3} \mathrm{SO}_{3}^{-}$. A signal of weaker intensity, corresponding to the singly charged

Table 1

Observed ions $(\mathrm{m} / \mathrm{z})$ in MALDI-TOF spectra of derivatives $\mathbf{2 a}-\mathbf{2} \mathbf{c}$

\begin{tabular}{|c|c|c|c|c|}
\hline \multirow[t]{2}{*}{ Assignment } & \multicolumn{4}{|c|}{$\mathrm{m} / \mathrm{z}$ values } \\
\hline & $2 a^{a}$ & $2 a^{b}$ & $2 \mathbf{b}^{\mathrm{a}}$ & $2 c^{a}$ \\
\hline$\left[\mathrm{Ru}\left(\mathrm{C}_{5} \mathrm{R}_{5}\right) \mathrm{C}_{6} \mathrm{H}_{5}\left(\mathrm{CH}_{2}\right)_{3} \mathrm{C}_{6} \mathrm{H}_{5} \mathrm{Ru}\left(\mathrm{C}_{5} \mathrm{R}_{5}\right)^{2+}+\mathrm{A}^{-}\right]^{+}$ & 673 & & 677 & 755 \\
\hline$\left[\mathrm{Ru}\left(\mathrm{C}_{5} \mathrm{R}_{5}\right) \mathrm{C}_{6} \mathrm{H}_{5}\left(\mathrm{CH}_{2}\right)_{3} \mathrm{C}_{6} \mathrm{H}_{5} \mathrm{Ru}\left(\mathrm{C}_{5} \mathrm{R}_{5}\right)\right]^{+}$ & 528 & & 528 & 668 \\
\hline$\left[\mathrm{Ru}\left(\mathrm{C}_{5} \mathrm{R}_{5}\right) \mathrm{C}_{6} \mathrm{H}_{5}\left(\mathrm{CH}_{2}\right)_{3} \mathrm{C}_{6} \mathrm{H}_{5} \mathrm{Ru}\right]^{+}$ & & 463 & & 533 \\
\hline$\left[\mathrm{Ru}\left(\mathrm{C}_{5} \mathrm{R}_{5}\right) \mathrm{C}_{6} \mathrm{H}_{5}\left(\mathrm{CH}_{2}\right)_{3} \mathrm{C}_{6} \mathrm{H}_{5}\right]^{+}$ & 362 & 362 & 362 & 432 \\
\hline$\left[\mathrm{Ru}\left(\mathrm{C}_{5} \mathrm{R}_{5}\right) \mathrm{C}_{6} \mathrm{H}_{5} \mathrm{CHCH}_{2}\right]^{+}$ & 270 & 270 & 270 & 340 \\
\hline$\left[\mathrm{Ru}\left(\mathrm{C}_{5} \mathrm{R}_{5}\right) \mathrm{C}_{6} \mathrm{H}_{5} \mathrm{CH}_{3}\right]^{+}$ & & & 258 & 328 \\
\hline$\left[\mathrm{C}_{6} \mathrm{H}_{6} \mathrm{RuC}_{5} \mathrm{R}_{5}\right]^{+}$ & 244 & 244 & 244 & \\
\hline
\end{tabular}

${ }^{a} \alpha$-Cyano-4-hydroxicinnamic acid.

b All-trans-retinoic acid.

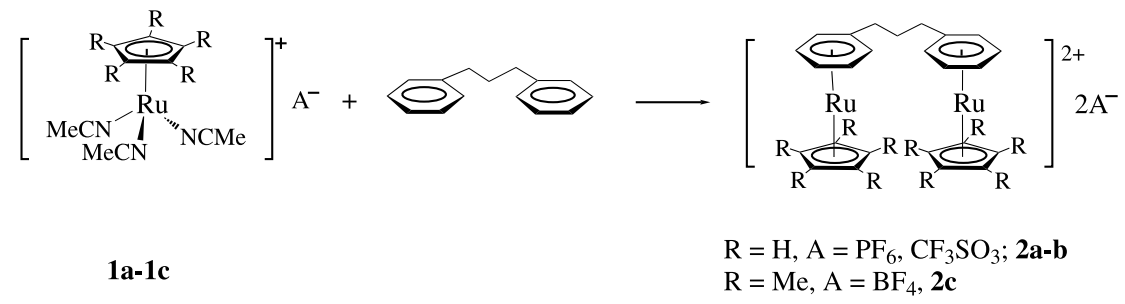

Scheme 2. Synthesis of model complexes $\mathbf{2 a - 2 c}$. 


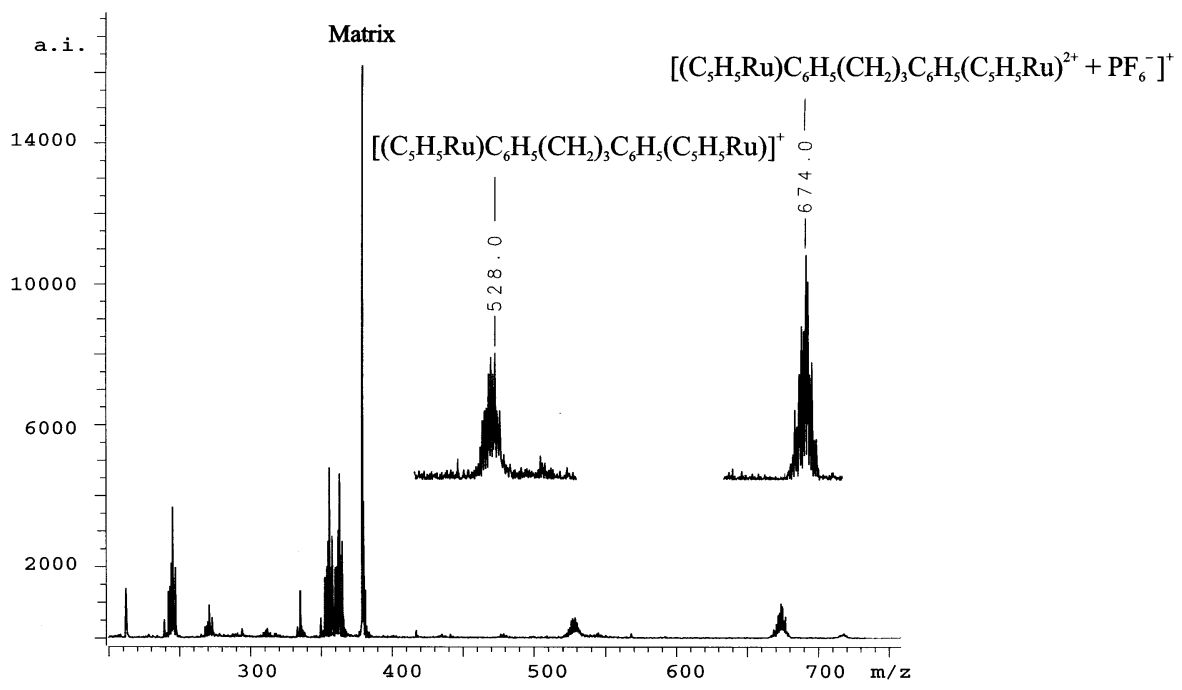

Fig. 4. MALDI mass spectrum of $\left[\mathrm{Ru}\left(\mathrm{C}_{5} \mathrm{H}_{5}\right)\left(\eta^{6}-\mathrm{C}_{6} \mathrm{H}_{5}\right)\left(\mathrm{CH}_{2}\right)_{3}\left(\eta^{6}-\mathrm{C}_{6} \mathrm{H}_{5}\right) \mathrm{Ru}\left(\mathrm{C}_{5} \mathrm{R}_{5}\right)\right]^{2+} \cdot 2 \mathrm{PF}_{6}^{-}$( $\alpha$-cyano-4-hydroxycinnamic acid matrix).

parent ion $\left[\mathrm{Ru}\left(\mathrm{C}_{5} \mathrm{R}_{5}\right)\left(\eta^{6}-\mathrm{C}_{6} \mathrm{H}_{5}\right)\left(\mathrm{CH}_{2}\right)_{3}\left(\eta^{6}-\mathrm{C}_{6} \mathrm{H}_{5}\right)-\right.$ $\left.\mathrm{Ru}\left(\mathrm{C}_{5} \mathrm{R}_{5}\right)\right]^{+}$, was also detected for all three derivatives $\mathbf{2 a}-\mathbf{c}$ as a result of loss of the counter anion and charge reduction by adding one electron. The ensuing radical species then appears to fragment to the ions presented in Table 1. A possible pathway for the fragmentation reaction is outlined in Scheme 3.

That singly charged positive ions are mainly observed is a well known feature of the MALDI technique. The pathway outlined in Scheme 3 is in line with the proposal that during the desorption event, highly precharged clusters, consisting of matrix, analyte and others ionic species embedded in the matrix crystals, are initially formed but cannot survive in the plume and undergo reduction to charge states 1 or 0 by trapping electrons derived from the matrix photoionization process. The radical species thus formed can subsequently suffer fragmentation and thus escape detection in the MALDI spectra [17].
This is particularly apparent when complex $\mathbf{2 a}$ is studied by MALDI-MS using all-trans-retinoic acid as matrix (Table 1). Neither the cluster ion $\left[\mathrm{Ru}\left(\mathrm{C}_{5} \mathrm{H}_{5}\right)\right.$ $\left.\left(\mathrm{C}_{6} \mathrm{H}_{5}\left(\mathrm{CH}_{2}\right)_{3} \mathrm{C}_{6} \mathrm{H}_{5}\right) \mathrm{Ru}\left(\mathrm{C}_{5} \mathrm{H}_{5}\right)^{2+}+\mathrm{PF}_{6}^{-}\right]^{+}$nor the singly charged parent ion $\left[\mathrm{Ru}\left(\mathrm{C}_{5} \mathrm{R}_{5}\right)\left(\mathrm{C}_{6} \mathrm{H}_{5}\left(\mathrm{CH}_{2}\right)_{3} \mathrm{C}_{6} \mathrm{H}_{5}\right)\right.$ $\left.\mathrm{Ru}\left(\mathrm{C}_{5} \mathrm{R}_{5}\right)\right]^{+}$were observed. Instead, we observe the same fragment ions - but with higher intensities - as with an $\alpha$-cyano-4-hydroxycinnamic acid matrix. The degree of fragmentation of the radical ion intermediates is obviously highly dependent on the matrix used $[4,16,17]$. This appears to be the reason why polymer fragmentation dominates when multiply charged ions, produced by an excess of the $\mathrm{Ru}\left(\mathrm{C}_{5} \mathrm{R}_{5}\right)$ reagent, are ionized in the all-trans-retinoic acid matrix, while no MS signals were obtained when the polystyrene-ruthenium complexes were studied in an $\alpha$-cyano-4-hydroxycinnamic acid matrix.

This analysis would indicate that a more fruitful way to generate metal-centered polystyrene ions would be to

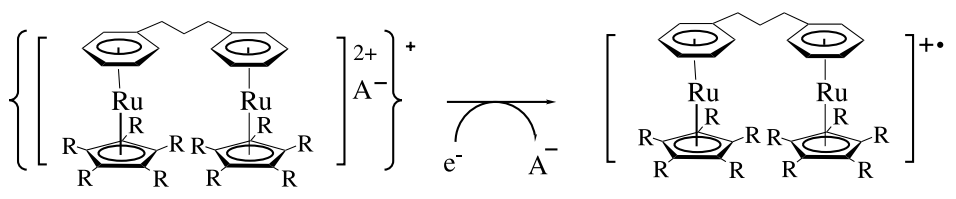

(Precharged cluster)

(Radical ion)

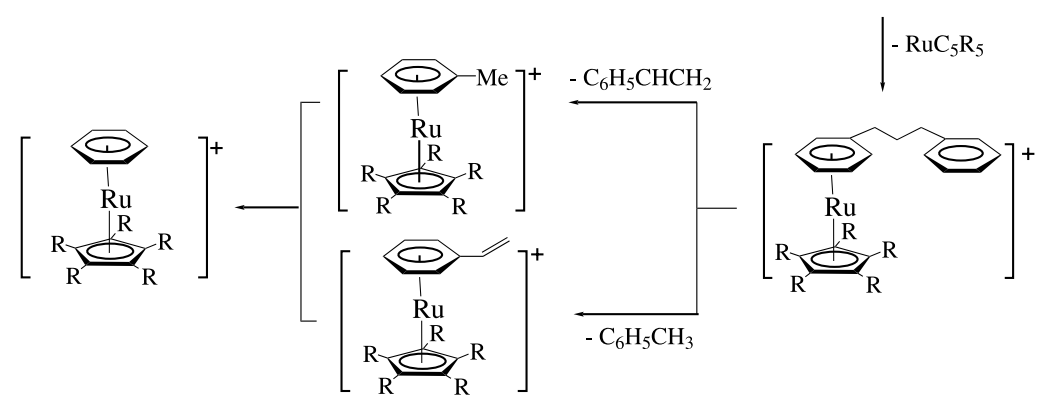

Scheme 3. Proposed pathway for ion formation in mass spectra of complexes $\mathbf{2 a}-\mathbf{2 c}$. 
bind neutral organometallic derivatives to the polystyrene chains, which can subsequently be photo-ionized without intervention of any counter anions.

\subsection{Organometallic modification of polypropene}

Some organometallic fragments are capable of cleaving aliphatic $\mathrm{C}-\mathrm{H}$ bonds. In many cases, isolable $\mathrm{M}$ alkyl or M(alkyl)(hydride) complexes are formed [18]. Such a process might make it possible to attach a metal center to a saturated hydrocarbon chain, and hence, to ionize even polymers containing no functional groups at all. When polypropene is generated by insertion-type polymerization catalysts, such as metallocene-based catalyst systems, most of the polymer chains do contain an unsaturated $\mathrm{H}_{2} \mathrm{C}=\mathrm{C}\left(\mathrm{CH}_{3}\right)$ - (2-propenyl) end group, however.

1,1-Disubstituted alkenes have been reported by Suzuki and coworkers to react with the trinuclear ruthenium pentahydride $\left(\mathrm{RuC}_{5} \mathrm{Me}_{5}\right)_{3}\left(\mu^{2}-\mathrm{H}\right)_{3}\left(\mu^{3}-\mathrm{H}\right)_{2}$ (3) to give a trinuclear $\mu^{3}$-alkyne- $\mu^{3}$-methylidyne species [19]. The pentahydride 3 as well as the final $\mu$-alkyne compounds are thermally rather stable; this makes these triruthenium clusters particularly valuable for our purposes.

Reaction of complex 3 with polypropene samples of $M_{\mathrm{n}} 2700(\mathrm{PD}=1.36)$ or $6100(\mathrm{PD}=1.37)$, in which ca. $60 \%$ of the chains contained a 2-propenyl end groups, (as inferred from ${ }^{1} \mathrm{H}-\mathrm{NMR}$ spectra), yielded after $24 \mathrm{~h}$ at $150{ }^{\circ} \mathrm{C}$ a dark red product whose THF solutions were analyzed by MALDI-TOF-MS, using all-trans-retinoic acid or dithranol as matrices. The spectra show a succession of molecular ions (Fig. 5), with typical peak to peak increments of $43 \mathrm{amu}$. The MALDI spectra were reproducible and no variations between target spots were noted. The average molar mass values measured by MALDI-MS are lower than those obtained by GPC. Similar observations have been noted in studies

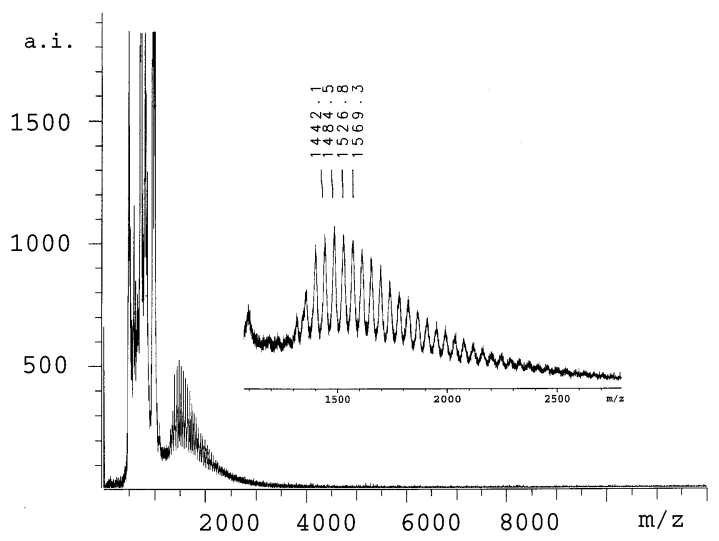

Fig. 5. MALDI mass spectrum of polypropene with $M_{\mathrm{n}}=6100$ and $\mathrm{PD}=1.37$ after reaction with $\left(\mathrm{RuC}_{5} \mathrm{Me}_{5}\right)_{3}\left(\mu^{2}-\mathrm{H}\right)_{3}\left(\mu^{3}-\mathrm{H}\right)_{2}$ (dithranol matrix). on other types of polymers with polydispersities greater than ca. 1.3 [20]. The overrepresentation of low-mass ions might also be due, however, to a bias in the reaction of the organometallic reagent toward shorter chains of polypropene. Longer-chain polypropene with $M_{\mathrm{n}} \approx$ $10000 \mathrm{~g} \mathrm{~mol}^{-1}$ did not give rise to any detectable ion signals in MALDI-MS by this procedure. Use of a norharmane matrix did not give any better results, even though this matrix has recently been reported to lead to efficient ionization of nonpolar polymers [21]. Nonetheless, to the best of our knowledge nonpolar polyethylene or poly(1-pentene) oligomers have been successfully ionized by $\mathrm{Ag}^{+}$addition in MALDITOF-MS only in the low mass range of $M_{\mathrm{n}}<1000$ amu $[11,12]$, such that the results reported here represent the first example of an MS-signal generation from polypropene samples with $M_{\mathrm{n}}>1000 \mathrm{amu}$.

In order to obtain some leads on the identity of the complex ions responsible for these polypropene-containing ions, we have investigated the reactions of the pentahydride cluster 3 with an excess of neat 1-eicosene $\left(\mathrm{CH}_{2}=\mathrm{CH}\left(\mathrm{CH}_{2}\right)_{17} \mathrm{CH}_{3}\right)$. When this reaction was carried out at $80{ }^{\circ} \mathrm{C}$, a red-violet reaction mixture is obtained after ca. $12 \mathrm{~h}$. In the ${ }^{1} \mathrm{H}$-NMR spectrum of this mixture the proton resonances of the terminal methylene group of 1-eicosene ( $\delta 5.72-5.89, \mathrm{~m}, 1 \mathrm{H} ; \delta 4.96-5.08, \mathrm{~m}, 2 \mathrm{H})$ have disappeared while a new multiplet signal appeared at $\delta$ 5.46-5.43. This is consistent with the selective cleavage of the two $\mathrm{C}-\mathrm{H}$ bonds at the terminal methylene carbon, probably with formation of the $\mu$ vinylidene complex (4) [19,22] (Scheme 4). A more complete characterization of the final compound by NMR techniques proved impossible since the high-field part of the spectra was obscured by the proton resonances of the eicosene methylene groups.

MALDI-TOF-MS analysis of THF solutions of this sample gave, with a dithranol matrix, mainly the two singly charged parent ions $\left[\left(\mathrm{RuC}_{5} \mathrm{Me}_{5}\right)_{3} \mathrm{H}_{x}(\mathrm{C}=\mathrm{CH}\right.$ $\left.\left.\left(\mathrm{CH}_{2}\right)_{17} \mathrm{CH}_{3}\right)+\mathrm{CH}_{3}\right]^{+}$and $\left[\left(\mathrm{RuC}_{5} \mathrm{Me}_{5}\right)_{3} \mathrm{H}_{x}(\mathrm{C}=\mathrm{CH}-\right.$ $\left.\left.\left(\mathrm{CH}_{2}\right)_{17} \mathrm{CH}_{3}\right)+2 \mathrm{CH}_{3}\right]^{+}$with $x$ being most likely 0 or 1 (Table 2). Signals of weaker intensity corresponding to different fragment ions were also observed. When the complex is ionized without any matrix, only one peak at $m / z=\left[\left(\mathrm{RuC}_{5} \mathrm{Me}_{5}\right)_{3} \mathrm{H}_{x}\left(\mathrm{C}=\mathrm{CH}\left(\mathrm{CH}_{2}\right)_{17} \mathrm{CH}_{3}\right)+\mathrm{CH}_{3}\right]^{+}$is observed (Fig. 6).

With regard to the puzzling appearance of one or two extra methyl groups in these complex ions, we note that ions with additional methyl groups were also observed

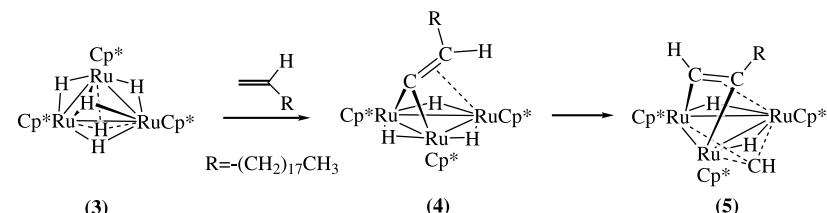

Scheme 4 
Table 2

Observed ions in MALDI-TOF spectra of derivative $\mathbf{3}$ and those of the reaction product between 3 and 1-eicosene (dithranol matrix)

\begin{tabular}{ll}
\hline Assignment & \multicolumn{2}{l}{$m / z$ values } \\
\cline { 2 - 2 } & $\mathbf{3} \quad \begin{array}{l}\text { Reaction pro- } \\
\text { duct }\end{array}$ \\
& \multicolumn{2}{c}{ duct } \\
\hline$\left[\left(\mathrm{RuC}_{5} \mathrm{Me}_{5}\right)_{3} \mathrm{H}_{x}\right]^{+}$ & 711 \\
{$\left[\left(\mathrm{RuC}_{5} \mathrm{Me}_{5}\right)_{3} \mathrm{H}_{x}+\mathrm{CH}_{3}\right]^{+}$} & 726 \\
{$\left[\left(\mathrm{RuC}_{5} \mathrm{Me}_{5}\right)_{3} \mathrm{H}_{x}+2 \mathrm{CH}_{3}\right]^{+}$} & 741 \\
{$\left[\left(\mathrm{RuC}_{5} \mathrm{Me}_{5}\right)_{3} \mathrm{H}_{x}+\mathrm{C}_{5} \mathrm{Me}_{5} \mathrm{Ru}^{+}\right.$} & 947 \\
{$\left[\left(\mathrm{RuC}_{5} \mathrm{Me}_{5}\right)_{3} \mathrm{H}_{x}\left(\mathrm{C}=\mathrm{CH}\left(\mathrm{CH}_{2}\right)_{17} \mathrm{CH}_{3}\right)+\mathrm{CH}_{3}\right]^{+}$} & 1003 \\
{$\left[\left(\mathrm{RuC}_{5} \mathrm{Me}_{5}\right)_{3} \mathrm{H}_{x}\left(\mathrm{C}=\mathrm{CH}\left(\mathrm{CH}_{2}\right)_{17} \mathrm{CH}_{3}\right)+2 \mathrm{CH}_{3}\right]^{+}$} & 1019 \\
\hline
\end{tabular}

when the trinuclear pentahydride $\mathbf{3}$ was analyzed alone (i.e. without addition of eicosene) by MALDI-TOF-MS (Table 2). Apparently, the triruthenium cluster, when ionized and deprived from some or all of its hydride ligands, becomes prone to incorporate $\mathrm{CH}_{3}$ groupspresumably derived from $\mathrm{C}_{5} \mathrm{Me}_{5}$ ligand units - in order to stabilize itself, most likely in form of a $\mu_{3}$-methylidyne complex (5) similar to that reported by Suzuki and coworkers [19]. Based on this notion, we propose that the ion $\left[\left(\mathrm{RuC}_{5} \mathrm{Me}_{5}\right)_{3} \mathrm{H}_{x}\left(\mathrm{C}=\mathrm{CH}\left(\mathrm{CH}_{2}\right)_{17} \mathrm{CH}_{3}\right)+\mathrm{CH}_{3}\right]^{+}$ has a structure analogous to that reported by these authors for a series of $\mu_{3}$-alkyne- $\mu_{3}$-methylidyne complexes.

We regard these results as a first entrance into a new methodology for direct mass spectrometric analysis of polyolefins by selective organometallic derivatization, which will require extension to a wide range of related organometallic reactions.

\section{Experimental}

\subsection{General procedure}

MALDI-MS measurements were performed on a Reflex time-of-flight instrument (Bruker-Franzen Analytik, Bremen, Germany) equipped with a SCOUT ion source, operating in the positive reflection mode with pulsed extraction. Ions were formed by a pulsed UV laser beam (nitrogen laser, $\lambda=337 \mathrm{~nm}$ ). ${ }^{1} \mathrm{H}-\mathrm{NMR}$ spectra were recorded on Bruker AC 250 spectrometer.

\subsubsection{Samples and reagents}

Polystyrene samples with $M_{\mathrm{n}}$ values of 1430,2450 , 5050, $39000,66000,135000$ and $560000(\mathrm{PD}=1.0)$ were gifts from Dr. Knoll (BASF AG). Polypropene with $M_{\mathrm{n}}$ values of $2700(\mathrm{PD}=1.36)$ and $6100(\mathrm{PD}=$ 1.37) were polymerized in our laboratories and analyzed by GPC. All matrices used as well as $\mathrm{AgNO}_{3}$ were purchased from Aldrich. Angiotensin II, bovine insulin b-chain, bovine ubiquitin and bovine carbonic anhy-

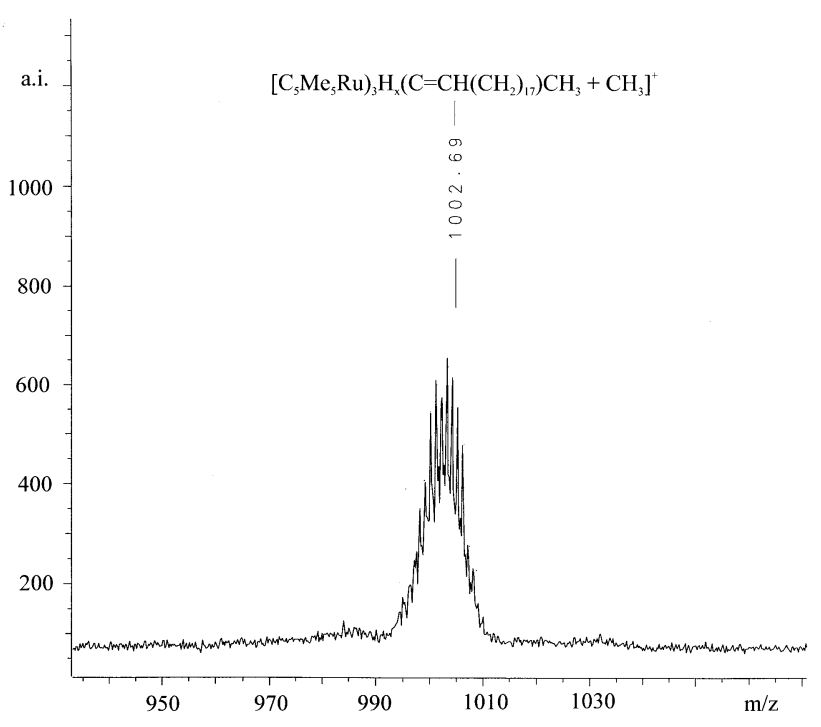

Fig. 6. MALDI mass spectrum of product of reaction between 1eicosene and $\left(\mathrm{RuC}_{5} \mathrm{Me}_{5}\right)_{3}\left(\mu^{2}-\mathrm{H}\right)_{3}\left(\mu^{3}-\mathrm{H}\right)_{2}$ (without matrix).

drase samples used for MS calibrations were obtained from Sigma. Tetrahydrofuran (THF) was treated with potassium hydroxide and then distilled over sodium metal. All organometallic synthesis manipulations were performed using an argon/vacuum manifold or a glove box under nitrogen atmosphere. 1,2-dichloroethane was dried over $\mathrm{CaH}_{2}$ and distilled before use. $\left[\mathrm{Ru}\left(\mathrm{C}_{5} \mathrm{H}_{5}\right)\right.$ $\left.\left(\mathrm{NCCH}_{3}\right)_{3}\right]\left[\mathrm{CF}_{3} \mathrm{SO}_{3}\right] \quad[13], \quad\left[\mathrm{Ru}\left(\mathrm{C}_{5} \mathrm{H}_{5}\right)\left(\mathrm{NCCH}_{3}\right)_{3}\right]\left[\mathrm{PF}_{6}\right]$ [14], $\left[\mathrm{Ru}\left(\mathrm{C}_{5} \mathrm{Me}_{5}\right)\left(\mathrm{NCCH}_{3}\right)_{3}\right]\left[\mathrm{BF}_{4}\right]$ [23] and $\left(\mathrm{RuC}_{5}-\right.$ $\left.\mathrm{Me}_{5}\right)_{3}\left(\mu^{2}-\mathrm{H}\right)_{3}\left(\mu^{3}-\mathrm{H}\right)_{2}$ [24] were prepared according to previous reports.

\subsubsection{Sample preparation}

Polymer samples for MALDI analysis were prepared by combining the analyte and matrix solutions. Typically, the modified polymer samples were dissolved in THF to prepare stock solutions with concentrations of ca. $5 \mathrm{mg} \mathrm{ml}^{-1}$. Dithranol or all-trans-retinoic acid solutions were prepared as $0.15 \mathrm{M}$ solutions in THF. The concentration of analyte in the final solution ranged from $30 \mathrm{nM}$ to $200 \mu \mathrm{M}$, depending on molecular weight, with the matrix concentration maintained at ca. $0.14 \mathrm{M}$. After brief mixing of the analyte and matrix, $0.3-0.5 \mu 1$ was added to the MALDI probe tip and allowed to airdry. Silver nitrate, when used, was dissolved in ethanol and added to the polymer-matrix solution.

Mass calibrations were performed externally. For polymers with $M_{\mathrm{n}}$ values between 1000 and 80000 , the protein standards listed above were used for calibration. Mass calibration for high molecular weight polymers $\left(M_{\mathrm{n}}>100000\right)$ was performed with polystyrene 135000 as external standard which was measured with an alltrans-retinoic acid matrix and silver nitrate as the cationization reagent. 
3.2. $\left[R u\left(\eta^{5}-C_{5} H_{5}\right)\left(\eta^{6}-C_{6} H_{5}\right)\left(C_{2}\right)_{3}\left(\eta^{6}-C_{6} H_{5}\right) R u\left(\eta^{5}-\right.\right.$ $\left.\left.\mathrm{C}_{5} \mathrm{H}_{5}\right)\right]\left[\mathrm{PF}_{6}\right]_{2}(\mathbf{2 a})$

To a solution of $1.0 \mathrm{~g}(2.30 \mathrm{mmol})$ of $\left[\mathrm{Ru}\left(\eta^{5}\right.\right.$ $\left.\left.\mathrm{C}_{5} \mathrm{H}_{5}\right)\left(\mathrm{NCCH}_{3}\right)_{3}\right]\left[\mathrm{PF}_{6}\right]$ (1a) in ca. $40 \mathrm{ml}$ of 1,2-dichloroethane was added $0.23 \mathrm{ml}(1.15 \mathrm{mmol})$ of 1,3-diphenylpropane. The slightly yellow solution was heated to $60-$ $70{ }^{\circ} \mathrm{C}$ for $3-4 \mathrm{~h}$. After allowing the mixture to come to room temperature (r.t.), the solvent was removed under reduced pressure and the white solid residue washed with small portions of pentane $(2 \times 10 \mathrm{ml})$ and dried in vacuo to yield $0.49 \mathrm{~g}(83 \%, 0.96 \mathrm{mmol})$ of pure $\left[\mathrm{Ru}\left(\eta^{5}\right.\right.$ $\left.\left.\mathrm{C}_{5} \mathrm{H}_{5}\right)\left(\eta^{6}-\mathrm{C}_{6} \mathrm{H}_{5}\right)\left(\mathrm{CH}_{2}\right)_{3}\left(\eta^{6}-\mathrm{C}_{6} \mathrm{H}_{5}\right) \mathrm{Ru}\left(\eta^{5}-\mathrm{C}_{5} \mathrm{H}_{5}\right)\right]\left[\mathrm{PF}_{6}\right]_{2}$ (2a). ${ }^{1} \mathrm{H}-\mathrm{NMR}\left(24{ }^{\circ} \mathrm{C}, 250 \mathrm{MHz}, \mathrm{CD}_{3} \mathrm{CN}\right) \delta 5.89-5.82$ $\left(\mathrm{m}, 10 \mathrm{H},-\mathrm{C}_{6} \mathrm{H}_{5}\right), 5.32\left(\mathrm{~s}, 10 \mathrm{H}, \mathrm{C}_{5} \mathrm{H}_{5}\right), 2.58-2.51(\mathrm{~m}$, $6 \mathrm{H},-\mathrm{CH}_{2}-$ ). MS (MALDI-TOF) see Table 1.

3.3. $\left[R u\left(\eta^{5}-C_{5} H_{5}\right)\left(\eta^{6}-C_{6} H_{5}\right)\left(C_{2}\right)_{3}\left(\eta^{6}-C_{6} H_{5}\right) R u\left(\eta^{5}-\right.\right.$ $\left.\left.\mathrm{C}_{5} \mathrm{H}_{5}\right)\right]\left[\mathrm{CF}_{3} \mathrm{SO}_{3}\right]_{2}(2 \boldsymbol{b})$

Treatment of $1.0 \mathrm{~g}(2.28 \mathrm{mmol})$ of $\left[\mathrm{Ru}\left(\eta^{5}-\mathrm{C}_{5} \mathrm{H}_{5}\right)\right.$ $\left.\left(\mathrm{NCCH}_{3}\right)_{3}\right]\left[\mathrm{CF}_{3} \mathrm{SO}_{3}\right],(\mathbf{1 b})$ with $0.22 \mathrm{ml}(1.14 \mathrm{mmol})$ of 1,3-diphenylpropane under a protocol analogous to that described for 2a, gave $0.46 \mathrm{~g}(80 \%, 0.91 \mathrm{mmol})$ of pure $\quad\left[\mathrm{Ru}\left(\eta^{5}-\mathrm{C}_{5} \mathrm{H}_{5}\right)\left(\eta^{6}-\mathrm{C}_{6} \mathrm{H}_{5}\right)\left(\mathrm{CH}_{2}\right)_{3}\left(\eta^{6}-\mathrm{C}_{6} \mathrm{H}_{5}\right) \mathrm{Ru}\left(\eta^{5}-\right.\right.$ $\left.\left.\mathrm{C}_{5} \mathrm{H}_{5}\right)\right]\left[\mathrm{CF}_{3} \mathrm{SO}_{3}\right]_{2} \quad(\mathbf{2 c}) .{ }^{1} \mathrm{H}-\mathrm{NMR}\left(24{ }^{\circ} \mathrm{C}, 250 \mathrm{MHz}\right.$, $\left.\mathrm{CD}_{3} \mathrm{CN}\right) \delta 6.16-5.98\left(\mathrm{~m}, 10 \mathrm{H},-\mathrm{C}_{6} \mathrm{H}_{5}\right), 5.32(\mathrm{~s}, 10 \mathrm{H}$, $\mathrm{C}_{5} \mathrm{H}_{5}$ ), 2.56-2.48 (m, 6H, $-\mathrm{CH}_{2}-$ ). MS (MALDI-TOF) see Table 1.

3.4. $\left[R u\left(\eta^{5}-C_{5} M e_{5}\right)\left(\eta^{6}-C_{6} H_{5}\right)\left(C_{2}\right)_{3}\left(\eta^{6}-\right.\right.$ $\left.\left.\mathrm{C}_{6} \mathrm{H}_{5}\right) \mathrm{Ru}\left(\eta^{5}-\mathrm{C}_{5} \mathrm{Me}_{5}\right)\right]\left[\mathrm{BF}_{4}\right]_{2}(2 \mathrm{c})$

Treatment of $1.0 \mathrm{~g}(2.24 \mathrm{mmol})$ of $\left[\mathrm{Ru}\left(\eta^{5}-\mathrm{C}_{5} \mathrm{Me}_{5}\right)\right.$ $\left.\left(\mathrm{NCCH}_{3}\right)_{3}\right]\left[\mathrm{BF}_{4}\right],(\mathbf{1 c})$ with $0.22 \mathrm{ml}(1.12 \mathrm{mmol})$ of $1,3-$ diphenylpropane under a protocol analogous to that described for $\mathbf{2 a}$ or $\mathbf{2 b}$, gave $0.45 \mathrm{~g}(78 \%, 0.87 \mathrm{mmol})$ of pure $\left[\mathrm{Ru}\left(\eta^{5}-\mathrm{C}_{5} \mathrm{Me}_{5}\right)\left(\eta^{6}-\mathrm{C}_{6} \mathrm{H}_{5}\right)\left(\mathrm{CH}_{2}\right)_{3}\left(\eta^{6}-\mathrm{C}_{6} \mathrm{H}_{5}\right) \mathrm{Ru}\left(\eta^{5}-\right.\right.$ $\left.\left.\mathrm{C}_{5} \mathrm{Me}_{5}\right)\right]\left[\mathrm{BF}_{4}\right]_{2} \quad$ (2b). ${ }^{1} \mathrm{H}-\mathrm{NMR} \quad\left(24{ }^{\circ} \mathrm{C}, \quad 250 \mathrm{MHz}\right.$, $\left.\mathrm{CD}_{3} \mathrm{CN}\right) \delta 5.79-5.69\left(\mathrm{~m}, 10 \mathrm{H},-\mathrm{C}_{6} \mathrm{H}_{5}\right), 2.43-2.37(\mathrm{~m}$, $\left.6 \mathrm{H},-\mathrm{CH}_{2}-\right), 1.95\left(\mathrm{~s}, 30 \mathrm{H}, \mathrm{C}_{5} \mathrm{Me}_{5}\right.$ ). MS (MALDI-TOF) see Table 1.

\subsection{Reaction of $\left[\mathrm{Ru}\left(\eta^{5}-\mathrm{C}_{5} \mathrm{H}_{5}\right)\left(\mathrm{NCCH}_{3}\right)_{3}\right]\left[\mathrm{PF}_{6}\right]$ with one equivalent of 1,3-diphenylpropane}

To a solution of $1.0 \mathrm{~g}(2.30 \mathrm{mmol})$ of $\left[\mathrm{Ru}\left(\eta^{5}\right.\right.$ $\left.\left.\mathrm{C}_{5} \mathrm{H}_{5}\right)\left(\mathrm{NCCH}_{3}\right)_{3}\right]\left[\mathrm{PF}_{6}\right],(\mathbf{1 a})$ in ca. $40 \mathrm{ml}$ of 1,2-dichloroethane was added at $0{ }^{\circ} \mathrm{C}, 0.45 \mathrm{ml}(2.30 \mathrm{mmol})$ of $1,3-$ diphenylpropane. After allowing the mixture to come to r.t., the yellow solution was stirred for 3-4 h. The solvent was removed under reduced pressure and the white solid residue washed with small portions of pentane $(2 \times 10 \mathrm{ml})$ and dried in vacuum. The ${ }^{1} \mathrm{H}$ NMR spectra of the solid showed the presence of resonances assignable to the ruthenium compound
$\left[\mathrm{Ru}\left(\eta^{5}-\mathrm{C}_{5} \mathrm{H}_{5}\right)\left(\eta^{6}-\mathrm{C}_{6} \mathrm{H}_{5}\right)\left(\mathrm{CH}_{2}\right)_{3}\left(\mathrm{C}_{6} \mathrm{H}_{5}\right)\right]\left[\mathrm{CF}_{3} \mathrm{SO}_{3}\right]$, together with those assigned to (2a). ${ }^{1} \mathrm{H}-\mathrm{NMR}\left(24{ }^{\circ} \mathrm{C}\right.$, $\left.\left.250 \mathrm{MHz}, \mathrm{CD}_{3} \mathrm{CN}\right)\right) \delta 7.35-7.19\left(\mathrm{~m}, 5 \mathrm{H},-\mathrm{C}_{6} \mathrm{H}_{5}\right), 6.12-$ $6.0\left(\mathrm{~m}, 5 \mathrm{H},-\mathrm{C}_{6} \mathrm{H}_{5}\right), 5.89-5.82\left(\mathrm{~m}, 10 \mathrm{H},-\mathrm{C}_{6} \mathrm{H}_{5}\right.$ of $\left.2 \mathrm{a}\right)$, $5.32\left(\mathrm{~s}, 10 \mathrm{H}, \mathrm{C}_{5} \mathrm{H}_{5}\right.$ of $\left.2 \mathrm{a}\right), 5.30\left(\mathrm{~s}, 5 \mathrm{H}, \mathrm{C}_{5} \mathrm{H}_{5}\right) 2.71-2.60$ $\left(\mathrm{m}, 6 \mathrm{H},-\mathrm{CH}_{2}-\right), 2.58-2.51\left(\mathrm{~m}, 6 \mathrm{H},-\mathrm{CH}_{2}-\right.$ of $\left.2 \mathrm{a}\right)$.

3.6. Reaction of 1-eicosene with $\left(\mathrm{Ru}_{5} \mathrm{Me}_{5}\right)_{3}\left(\mu^{2}\right.$ $H)_{3}\left(\mu^{3}-H\right)_{2}(\mathbf{3})$

Derivative $3(0.10 \mathrm{~g}, 0.14 \mathrm{mmol})$ was heated together with 1-eicosene $(0.5 \mathrm{~g}, 1.80 \mathrm{mmol})$ in a Teflon-capped ampule to $60{ }^{\circ} \mathrm{C}$ for at least $12 \mathrm{~h}$. The THF solutions of the resulting oily violet residue were analyzed by MALDI-MS (Table 2).

\subsection{Reaction of polystyrene samples with $\left[R u\left(\eta^{5}-\right.\right.$ $\left.\left.\mathrm{C}_{5} \mathrm{H}_{5}\right)\left(\mathrm{NCCH}_{3}\right)_{3}\right]\left[\mathrm{PF}_{6}\right]$}

Following a general protocol, 10-20 mg of polystyrene were reacted with one to three equivalents of 1a (from a $2.5 \times 10^{-6} \mathrm{M}$ solution of $\mathbf{1 a}$ in 1,2-dichloroethane). The mixture was heated to $80{ }^{\circ} \mathrm{C}$ for $30 \mathrm{~min}$ and the solvent was removed under reduced pressure to yield a white powder residue. THF solutions of this solid were analyzed by MALDI-MS.

\subsection{Reaction of polypropene samples with \\ $\left(\mathrm{Ru} \mathrm{C}_{5} \mathrm{Me}_{5}\right)_{3}\left(\mu^{2}-\mathrm{H}\right)_{3}\left(\mu^{3}-\mathrm{H}\right)_{2}, \quad(\mathbf{3})$}

Polypropene (PP) samples were heated to $150{ }^{\circ} \mathrm{C}$ under vacuum for at least $24 \mathrm{~h}$ prior to use to eliminate traces of water and/or ethanol, which might contaminate the polymer. Following a general protocol, 100$150 \mathrm{mg}$ of the PP sample was heated with $10 \mathrm{mg}$ of derivative 3 in a Teflon-capped ampule to $120-150{ }^{\circ} \mathrm{C}$ for about $12 \mathrm{~h}$. The THF solutions of the resulting oily red residue were analyzed by MALDI-MS.

\section{Acknowledgements}

We thank Viorel Mocanu for help with initial MALDI-MS measurements, Klaus Hägele for technical help at the MALDI-MS spectrometer and Dr. Konrad Knoll (BASF GmbH) for gifts of polymer standards.

\section{References}

[1] (a) W.F. Maier, Angew. Chem. Int. Ed. Engl. 38 (1999) 1216; (b) T.R. Boussie, C. Coutard, H. Turner, V. Murphy, T.S. Powers, Angew. Chem. Int. Ed. Engl. 37 (1998) 3272;

(c) S. Brocchini, K. James, V. Tangpasuthadol, J. Kohn, J. Am. Chem. Soc. 119 (1997) 4553.

[2] (a) T. Bein, Angew. Chem. Int. Ed. Engl. 38 (1999) 323; (b) M.T. Reetz, M.H. Becker, K.M. Kühling, A. Holzwarth, 
Angew. Chem. Int. Ed. Engl. 37 (1998) 2647;

(c) A.C. Cooper, L.H. McAlexander, D.H. Lee, M.T. Torres, R.H. Crabtree, J. Am. Chem. Soc. 120 (1998) 9971;

(d) A. Holzwarth, H.W. Schmidt, W.F. Maier, Angew. Chem. 37 (1998) 2644

[3] J.W. Szewczyk, R.L. Zuckerman, R.G. Bergman, J.A. Ellman, Angew. Chem. 113 (2001) 222

[4] (a) M.W.F. Nielen, Mass Spectrom. Rev. 18 (1999) 309;

(b) S.D. Hanton, Chem. Rev. 101 (2001) 527 (and references therein).

[5] M.L. Vestal, Chem. Rev. 101 (2001) 361.

[6] F. Hillenkamp, M. Karas, R.C. Beavis, B.T. Chait, Anal. Chem. 63 (1991) 1193A.

[7] D.C. Schriemer, L. Li, Anal. Chem. 68 (1996) 2721.

[8] (a) U. Bahr, A. Deppe, M. Karas, F. Hillenkamp, U. Giessmann, Anal. Chem. 64 (1992) 2866;

(b) Z. Mincheva, P. Hadjieva, V. Kalcheva, R. Seraglia, P. Traldi,

M. Przybylski, J. Mass Spectrom. 36 (2001) 626;

(c) S. Servaty, W. Köhler, W.H. Meyer, C. Rosenauer, J. Spickermann, M.J. Räder, G. Wegner, A. Weier, Macromolecules 31 (1998) 2468;

(d) E.R.E. van der Hage, M.C. Duursma, R.M.A. Heeren, J.J. Boon, M.W.F. Nielen, A.J.M. Weber, C.G. de Koster, N.K. de Vries, Macromolecules 30 (1997) 4302;

(e) H. Lee, W. Lee, T. Chang, S. Choi, D. Lee, H. Ji, W.K Nonidez, J.W. Mays, Macromolecules 32 (1999) 4143.

[9] (a) T. Yalcin, Y. Dai, L. Li, J. Am. Soc. Mass. Spectrom. 9 (1998) 1303;

(b) H. Chen, B. Guo, Anal. Chem. 69 (1997) 4399;

(c) T. Yalcin, D. Schriemer, L. Li, J. Am. Soc. Mass Spectrom. 8 (1997) 1220 ;

(d) H. Zhu, T. Yalcin, L. Li, J. Am. Soc. Mass Spectrom. 9 (1998) 275.

[10] S. Fotti, G. Montaudo, Mass Spectrometry of Large Molecules, Elsevier, Amsterdam, 1985, pp. 283-301.

[11] U. Wahner, R. Brüll, H. Pasch, H.G. Raubenheimer, R. Sanderson, Angew. Makromol. Chem. 270 (1999) 49.

[12] (a) K. Ludányi, A. Dallos, Z. Kühn, K. Vékey, J. Mass Spectrom. 34 (1999) 264

(b) J.H. Gross, K. Vékey, A. Dallos, J. Mass Spectrom. 36 (2001) 522.

[13] M. Stebler-Röthlisberger, A. Ludi, Polyhedron 5 (1986) 1217.
[14] T.P. Gill, K.R. Mann, Organometallics 1 (1982) 485.

[15] (a) M.A. Benett, K. Khan, E. Wenger, in: D.F. Schriver, M.I. Bruce (Eds.), Comprenhensive Organometallic Chemistry II, vol. 7, Pergamon, 1995 , pp. 530-540;

(b) I. Chávez, M. Otero, E. Román, U. Müller, J. Organomet. Chem. 427 (1992) 369;

(c) B. Chaudret, G. Chung, Y.S. Huang, J. Chem. Soc. Chem. Commun. (1990) 749.;

(d) U. Koelle, M.H. Wang, Organometallics 9 (1990) 195.

[16] R. Zenobi, R. Knochmuss, Mass Spectrom. Rev. (1998) 337.

[17] M. Karas, M. Glückmann, J. Schäfer, J. Mass Spectrom. 35 (2000) 1 (and references therein).

[18] (a) R.G. Bergman, Science 223 (1984) 902;

(b) M.J. Burk, R.H. Crabtree, D.V. McGrath, J. Chem. Soc. Chem. Commun. (1985) 1829.;

(c) B.A. Amdtsen, R.G. Bergman, Science 270 (1995) 1970;

(d) A.E. Shilov, G.B. Shul'pin, Chem. Rev. 97 (1997) 2879.

[19] T. Takemori, A. Inagaki, H. Suzuki, J. Am. Chem. Soc. 123 (2001) 1762.

[20] (a) H.C.M. Byrd, C.N. McEwen, Anal. Chem. 72 (2000) 4568;

(b) S.D. Hanton, X.M. Liu, Anal. Chem. 72 (2000) 4550;

(c) C. Jackson, B. Larsen, C. McEwen, Anal. Chem. 68 (1996) 1303;

(d) R.M. Whittall, D.C. Schriemer, L. Li, Anal. Chem. 69 (1997) 2734;

(e) G. Wilczek-Vera, Y. Yu, K. Waddell, P.O. Danis, A. Eisenberg, Rapid Commun. Mass Spectrom. 13 (1999) 764;

(f) D. Vitalini, P. Mineo, E. Scamporrin, Macromolecules 30 (1997) 5285.

[21] H. Nonami, K. Tanaka, Y. Fukuyama, R. Erra-Balsells, Rapid Commun. Mass Spectrom. 12 (1998) 285.

[22] (a) T. Takemori, H. Suzuki, M. Tanaka, Organometallics 15 (1996) 4346;

(b) H. Adams, L.J. Gill, M.J. Morris, Organometallics 15 (1996) 4183;

(c) D. Seyferth, J.B. Hoke, M. Cowie, A.D. Hunter, J. Organomet. Chem. 346 (1988) 91;

(d) M. Green, A.G. Orpen, C.J. Schaverien, J. Chem. Soc. Dalton Trans. (1989) 1333.

[23] P.J. Fagan, M.D. Ward, J.C. Calabrese, J. Am. Chem. Soc 111 (1989) 1698.

[24] H. Suzuki et al., personal communication. 